University for Business and Technology in Kosovo

UBT Knowledge Center

Oct 27th, 4:45 PM - 6:15 PM

\title{
Economic Aspect of the Electricity Production in Subsidiary MPC Oslomej
}

Imer Zenku

University for Business and Technology, imer.zenku@ubt-uni.net

Follow this and additional works at: https://knowledgecenter.ubt-uni.net/conference

Part of the Bioresource and Agricultural Engineering Commons

\section{Recommended Citation}

Zenku, Imer, "Economic Aspect of the Electricity Production in Subsidiary MPC Oslomej" (2017). UBT International Conference. 141.

https://knowledgecenter.ubt-uni.net/conference/2017/all-events/141

This Event is brought to you for free and open access by the Publication and Journals at UBT Knowledge Center. It has been accepted for inclusion in UBT International Conference by an authorized administrator of UBT Knowledge Center. For more information, please contact knowledge.center@ubt-uni.net. 


\title{
Economic Aspect of the Electricity Production in Subsidiary MPC Oslomej
}

\author{
Imer Zenku \\ University Education for Business and Technology UBT, Str. Kalabria p.n. 10000 \\ Prishtina, Kosova \\ imer.zenku@ubt-uni.net
}

\begin{abstract}
The need to increase the production of electricity in the Subsidiary MPC Oslomej (Mining Power Complex-Oslomej), which operates as part of JSC ELEM (Macedonian Power Plants), 100\% state owned company, represents a significant economic activity.

Therefore, the analysis in this paper focuses and aims at the economic aspect of the current electricity production, that is, the impact of the expenditures of the Subsidiary on the price of electricity produced by ELEM JSC, a price also regulated by the Energy Regulatory Commission of the Republic of Macedonia (ERC).

This shall draw attention to the necessity to timely prepare and adjust the industrial complex for operation in conditions of achieving and maintaining company competitiveness advantage in a fully liberalized electricity market in the Republic of Macedonia, expected in the year 2020. In this context, the development of the Subsidiary and the extension of the operational life of TPP Oslomej (Thermo Power Plants-Oslomej) stand as the top priority of ELEM JSC, and support the general orientation of the Republic of Macedonia towards the European trends.
\end{abstract}

Keywords: economic aspect, electricity, production, expenditures

\section{Introduction}

A very important element for development of the economy of each country is of course the electricity production sector together with its production facilities. In the context of MPC Oslomej, as the second largest production facility part of ELEM JSC, it is very important for the electric energy system as a whole, in terms of employment and economic development of the municipality, the region and the country. The plant has an installed capacity of $125 \mathrm{MW}$, and in the period (2008-2011) it contributed with over $10 \%$ of the total electricity production, while in the total electricity production generated from thermal power plants of ELEM JSC it contributed with $13 \%$. The total electricity production to the grid for the period $1980-2016$ amounts to 17 077269 [MWh], which represents 85.5\% of its total planned production of 19968172 [MWh], reaching an average annual production of 461547 [MWh] [10]. In recent years, that is from 2012 onwards the production of electricity in TPP Oslomej drastically decreases, and does not fulfill the anyway drastically reduced plan for annual production.

Taking into consideration all of the above, including the need for increasing electricity production in the country as a whole, and ELEM JSC, i.e. MPC Oslomej especially, this paper is aiming to indicate to the current operation of MPC Oslomej, i.e. to the economic aspect of electricity production, and as an integral part the necessity to improve the efficiency and effectiveness of its future operation and development through modernization and sophistication of the technological processes. 
This means preparation and adjustment of the industrial complex for operation in conditions of achieving and maintaining company competitiveness advantage in a fully liberalized electricity market in the Republic of Macedonia.

In this context, the paper is composed of three parts, where the first part analyzes the electricity price of the regulated producer ELEM JSC. The second part includes an analysis of the current electricity production of MPC Oslomej, while the third part continues with the analysis of the production expenses and their impact on the determined electricity production price of ELEM JSC. The purpose of this is to indicate to the need of finding an adequate and economically viable solution for further productive operations, in order to meet the increasing needs of the consumers in the Republic of Macedonia. The paper ends with a number of conclusions.

\section{Electricity price of the regulated producer ELEM JSC}

The regulated producer ELEM JSC is obliged to submit a request to the Energy Regulatory Commission (ERC) of the Republic of Macedonia in order to receive an approval for Maximum Allowed Revenue (MAR) and price for regulated activity- electricity production.

In attachment to the request, despite the required documentation, ELEM JSC also submits data on the planned operational expenses of the production facilities which produce electricity as part of ELEM JSC including:

1. MPC "Bitola" - Bitola, with total installed capacity of $675 \mathrm{MW}$,

2. MPC "Oslomej" - Oslomej, with total installed capacity of $120 \mathrm{MW}$,

3. HPP "Globochica" - Struga, with total installed capacity of $42.56 \mathrm{MW}$,

4. HPP "Shpilje" - Debar, with total installed capacity of $84 \mathrm{MW}$,

5. HPP "Mavrovo" - Gostivar, with total installed capacity of $182 \mathrm{MW}$,

6. HPP "Treska" - Skopje, with total installed capacity of $80 \mathrm{MW}$,

7. HPP "Tikvesh" - Kavadarci, with total installed capacity of 114.48 MW.

In this context, in accordance with the Rulebook on electricity prices, ERC regularly holds a preparatory session, where amongst other issues the "Draft - Materials for approval of maximum allowed revenue in conducting the following regulated energy related activities: electricity production, transmission of electricity, electricity market organization and management, electricity distribution, and supply of electricity to tariff consumers" are discussed.

This preparatory session is attended by: members of the Energy Regulatory Commission, representatives of AD TPP NEGOTINO, ELEM JSC, MEPSO AD - Skopje, EVN Macedonia AD Skopje, representatives of the Cabinet of the Deputy Prime Minister of the Macedonian Government, representatives of the Ministry of Economy, the Commission on Protection of Competition, the Energy Agency of the Republic of Macedonia, Chamber of Commerce of the Republic of Macedonia, Macedonian Chambers of Commerce, as well as representatives of the Council for Protection of Consumers.

Then, considering the Request and the performed analysis of the submitted data by ELEM JSC, based on the Law on Energy [7] and the Rulebook [9] ERC makes a Decision [5] by which ELEM JSC is allowed to have a maximum allowed revenue and a determined price for conducting regulated energy related activity - electricity production, given in Table $1[2,3,5,10]$ for the period 2011-2015. 
Table 1 Operation data of TPP Oslomej in the period 2011-2015

\begin{tabular}{|c|c|c|c|c|c|}
\hline & 2011 & 2012 & 2013 & 2014 & 2015 \\
\hline \multicolumn{6}{|c|}{ JSC ELEM } \\
\hline $\begin{array}{l}\text { 1. Planned of ELEM JSC } \\
\text { [GWh] }\end{array}$ & 6075 & 5700 & 5787 & 5797 & 5091 \\
\hline $\begin{array}{l}\text { 2. Production of ELEM JSC } \\
\text { [GWh] }\end{array}$ & 6043 & 5370 & 5113 & 4535 & 4742 \\
\hline $\begin{array}{l}\text { 3. Total expenses of ELEM JSC } \\
\text { [million } € \text { ] }\end{array}$ & 244.63 & 262.87 & 255.42 & 219.79 & 216.67 \\
\hline $\begin{array}{l}\text { 4. Approved regulated } \\
\text { maximum income of ELEM } \\
\text { JSC [million } € \text { ] }\end{array}$ & 231.35 & 215.88 & 246.21 & 259.51 & 251.73 \\
\hline $\begin{array}{l}\text { 5. Determined price of } \\
\text { electricity produced by ELEM } \\
\text { JSC [€/MWh] }\end{array}$ & 34.51 & 35.91 & 39.70 & 40.90 & 41.04 \\
\hline \multicolumn{6}{|c|}{$\begin{array}{ll} & \text { Subsidiary TPP OSLOMEJ } \\
\end{array}$} \\
\hline 6. Plan. product. grid [GWh] & 601 & 601 & 505.2 & 349.4 & 227 \\
\hline 7. Actual product. grid [GWh] & 587 & 505 & 169 & 190 & 107 \\
\hline 8. Actual /Planned [\%] & 97.67 & 84.0 & 33.5 & 54.3 & 47.1 \\
\hline $\begin{array}{l}\text { 9. Actual / Production of ELEM } \\
\text { JSC [\%] }\end{array}$ & 9.71 & 9.40 & 3.31 & 4.19 & 2.26 \\
\hline $\begin{array}{l}\text { 10. Revenues from the actual } \\
\text { production grid [million } € \text { ] }\end{array}$ & 20.26 & 18.13 & 6.70 & 7.77 & 4.39 \\
\hline $\begin{array}{l}\text { 11. Total expenses of TPP } \\
\text { Oslomej [million } € \text { ] }\end{array}$ & 32.11 & 32.87 & 29.61 & 25.35 & 21.33 \\
\hline $\begin{array}{l}\text { 12. Price of produced el. per } \\
\text { generator in TPP Oslomej } \\
{[€ / M W h]}\end{array}$ & 48.99 & 57.92 & 157.9 & 116.2 & 169.8 \\
\hline $\begin{array}{l}\text { 13. Uncovered expenses of TPP } \\
\text { Oslomej [million } € \text { ] }\end{array}$ & 11.85 & 14.74 & 22.91 & 17.58 & 16.94 \\
\hline $\begin{array}{l}\text { 14. The impact of uncovered costs } \\
\text { of the Subsidiary on expenses of } \\
\text { ELEM JSC [\%] }\end{array}$ & 4.84 & 5.61 & 8.97 & 8.00 & 7.82 \\
\hline $\begin{array}{l}15 . \quad \text { Difference } \\
\text { determined and real price of } \\
\text { electricity produced by ELEM } \\
\text { JSC }[€ / \mathrm{MWh}]\end{array}$ & 1.67 & 2.01 & 3.56 & 3.27 & 3.21 \\
\hline
\end{tabular}

\section{Analysis of the current electricity production in MPC Oslomej}

The planned electricity production of MPC “Oslomej” for the period 2011 - 2015 was reduced each year due to lack of coal, and was particularly reduced in 2015 , for about $35 \%$ compared to 2014, and 62\% compared to 2011. Despite the reduced planned production, it additionally faced drastically reduced actual production, thus failing to achieve the anyway reduced annual production plan (Table 1), and this trend of drastic reduction still continues today.

At the same time, the participation of MPC Oslomej in the achieved production of electricity, for the same period, in the total electricity production of ELEM JSC drastically reduced from $9.71 \%$ in 2011 down to $2.26 \%$ in 2015 . This led to an increase of the produced electricity price per generator, which amounted to $48.99 € / \mathrm{MWh}$ in 2011 , and reached $169.8 € / \mathrm{MWh}$ in 2015 (Table 
1). This shows an extremely unacceptable electricity production, jeopardizing the market position, competitiveness and the position in the event of privatization of the company.

All of the above is a solid evidence in favor of the need for an urgent modernization of the thermal power plant, in accordance with the fuel supply options for TPP Oslomej, given in the analysis of ELEM [4] including: domestic lignite, imported lignite, natural gas, and imported high calorific value coal. The option for long-term supply of imported coal having a high calorific value of $25 \mathrm{MJ} / \mathrm{kg}$ and the modernization of the thermal power plant was elaborated in the Feasibility Study [1].

Despite all of this, neither clear instructions have been given, nor was a final decision regarding the option for extension of the operation of TPP Oslomej made. The opposite scenario would mean cease of operations and closing down of MPC Oslomej, generating the need for additional annual import of electricity of $600 \mathrm{GWh}$, which would cost 700 million euro for a period of 15 years [6].

The modernization of the thermal power plant would contribute to the increase of the extremely reduced production in recent years, as well as the actual achieved operation time with an average annual production of about $800 \mathrm{GWh}$ of electricity with 7,500 hours spent in operation. At the same time the installed capacity of the plant would increase for additional 7.6 MW, from the existing $125 \mathrm{MW}$ to $132.6 \mathrm{MW}$ for the modernized power plant.

The purpose of this is to return to the normal operational regime, to increase the economically viable production, thus extending the operational life of TPP Oslomej, which is especially important for the development of the municipality, since the monthly income of the employees represents a substantial financial turnover of monthly assets for the municipality. This financial turnover exceeds half a million euro per month.

Taking into account all of the above it is necessary for the new Government of the Republic of Macedonia to make a decision to modernize TPP Oslomej in accordance with the current European directives on large combustion plants.

\section{Analysis of the impact the MPC Oslomej's expenses have on the determined price of electricity production of ELEM JSC}

The total expenses of MPC Oslomej are reducing from year to year and in 2015 the reduction amounts to $33.57 \%$ compared to expenses in 2011. On the other hand, despite reduced expenses there is an even more drastic revenue reduction due to actual production reduction with a reduction in 2015 by $78.33 \%$ compared to the revenue in 2011 . Consequently, there is an increase in the price of produced electricity per generator, which in 2015 has increased by 3.46 times compared to 2011.

Despite the decrease in total expenses, due to the drastic decrease of revenue, there is an increase of uncovered costs amounting to $42.95 \%$ in 2015 compared to 2011 . These expenses have direct impact on the expenses of ELEM JSC and this participation amounts to 7.82\% in 2015, or has increased by $61.57 \%$ compared to 2011 . Hence, from the percentage of uncovered costs in the determined price from electricity produced by ELEM JSC the difference in price between the determined and the real electricity price produced by ELEM JSC can be concluded. This difference in price represents the price with which MPC Oslomej burdens the price determined by ERC and in 2015 it amounts to $3.21 € / \mathrm{MWh}$, or in other words increased by $92.21 \%$ compared to 2011 (Table 1). It can be noticed in the table that this difference in price has also existed in 2011 when there was solid production, but the difference is in the fact that the price is much lower, and there is also a certain amount of produced electricity which directly influences the reduction of imported electricity dependence of the country. The difference in price appearing due to the continuously decreasing production of MPC Oslomej also participates in the final price of tariff consumers. 


\section{Summary}

This work is of great importance as it discusses the economic aspect of electricity produced by MPC Oslomej through analysis of the regulated price of electricity produced by ELEM JSC, production and expenses of the Subsidiary which have a direct impact on the regulated price. All this serves to indicate the activities which need to be undertaken in order to improve and increase the performance of MPC Oslomej which would result in improvement and increase of performances of ELEM JSC which would contribute to sustainable company competitiveness which is still not present due to regulated production capacities and this competitiveness is expected in 2020 .

In the globalization era and as an imperative of the modern economy, in the current situation, the increase of production of MPC Oslomej means at least reaching and implementing of the planned production, which would to certain extent influence the reduction of the price of electricity produced by MPC Oslomej.

Uncovered costs have a direct impact in the increase of the regulated price of electricity produced by ELEM JSC and they can be lowered, and even eliminated by increasing the production, or the revenue, which in this case is possible only through modernization oft he production capacity. Having said this, the new Government of the Republic of Macedonia should, as soon as possible, make a specific and final decision on the modernization appropriate to the secured quanity and quality of coal (lignite or high-calorific value coal) or natural gas. This will enable the extension of TPP Oslomej's operational life and economically justified production.

\section{References}

1. . AF-Consult Switzerland Ltd: Modernization of TPP Oslomej-2700, Feasibility study-March (2015)

2. . ELEM JSC: Annual Reports for the years 2011, 2012, 2013, 2014 and 2015, Skopje (2011-2015) Retrieved from http://www.elem.com.mk/?page_id=530\&lang=en

3. ELEM JSC: Financial Results for the years 2011, 2012, 2013, 2014 and 2015, Skopje (2011-2015) Retrieved from http://www.elem.com.mk/?page_id=530\&lang=en

4. . ELEM JSC: Qualitative and quantitative analysis of options for supplying fuel to TPP Oslomej, Skopje December (2014) p.8

5. . Energy Regulatory Commission of the Republic of Macedonia: Decisions on approval of regulated maximum income and price for performing the regulated energy activity electricity generation of JSC ELEM-Skopje for the years 2011, 2012, 2013, 2014 and 2015, Skopje (2011-2015) Retrieved from http://www.erc.org.mk/pages.aspx?id=33

6. . Government of the Republic of Macedonia: Programme for implementation of strategy for energy development in the Republic of Macedonia for the period 2013 to 2017, Official Gazette of the Republic of Macedonia, no.50/2013, Skopje (2013) p.21

7. . Law on Energy: Official Gazette of the Republic of Macedonia, no.16/11, 136/11, 79/13,164/13, 41/14, 151/14, 33/15

8. . Republic of Macedonia, UKIM, Mechanical Engineering - Skopje: Study to assess the impact on the environment and socio-economic aspects (ESIA) of the project for modernization of TPP Oslomej- Oslomej, Skopje April (2015) p.63 
9. Rulebook on Prices of Electricity of Tariff Consumers: Official Gazette of the Republic of Macedonia, no.21/11, 168/11, 135/12

10. . TPP Oslomej: Annual Reports, Production in TPP Oslomej, for the years 2011, 2012, 2013, 2014, 2015 and 2016, Oslomej (2011-2016) 